\title{
Some Aspects of Molding Technology of Posolskaya Pottery in the South of Central Siberia
}

\author{
Ivan M. Berdnikov and Ilia V. Ulanov* \\ Irkutsk State University \\ 1 K. Marx Str., Irkutsk, 664003, Russia
}

Received 06.11.2014, received in revised form 12.12.2014, accepted 10.01.2015

\begin{abstract}
Pottery of Posolskaya type was highlighted in the 1970s and was named by the eponymous multilayer archeological site Posolskaya (Southern Baikal region). In various embodiments, Posolskaya ceramics is widespread in the south of Eastern Siberia. Intensive research of the multilayer stratified objects in the south of Central Siberia allowed to determine its age. At this stage of research its existence in the region can be dated to a wide interval - 6900-4100 years ago (Uncalibrated age), the boundaries of which require clarification. As a result of the analysis of the Posolskaya vessels from the archeological site named after Generalov (River Chuna) some aspects of the molding technique were identified. It was found that they had been constructed from wide tapes and had been stamped thoroughly. On the two vessels were found peculiar techniques that previously had been observed on the materials of the Bronze Age in Western Siberia. Each subsequent tape should overlap the previous tape dried up, the outer surface of which was stamped with a cord mallet and was treated in the same way. As a result, the negative junction mirror imprinted prints of the cords with the dried positive tape. There were two options of molding of Posolskaya type vessels: from the mouth of the mold without the use of the base and the bottom-up and with a split of the body and the bottom. The diagnosis of the technique described above is the key to the reconstruction of the molding process of vessels of Posolskaya type. For further identification of the type of the program and design one should conduct a series of additional experimental studies.
\end{abstract}

Keywords: Eastern Siberia, Neolithic technology of ancient pottery, ceramics of Posolskaya type, molding technique.

The work was completed as part of research project X.104.1.1, Institute of Archaeology and Ethnography $S B R A S$.

Research area: history.

\section{Introduction}

Posolskaya pottery was singled out certain time ago by L.P. Khlobystin and was named after the archeological site Posolskaya, located in the Kabansk district of Buryatia (south-east coast of the Lake Baikal) (Khlobystin, 1978, p. 96), since that time the largest collection of finds came from its excavations. The multilayer archeological site Posolskaya was opened in 1949 by A.P. Okladnikov and was studied intermittently

C) Siberian Federal University. All rights reserved

* Corresponding author E-mail address: yan-maiski@yandex.ru 
from 1959 to 1990 by Buryat, Chita (Tsydenova, Khamzina 2006: 323) and Irkutsk archaeologists (excavations by A.A. Khamzin, 1989).

N. Saveliev singled out Posolskaya ceramics in a separate ceramic stratum, "coming to the type" (Saveliev, 1989: 23). Currently, there is every reason to highlight the Posolskaya type of ceramics, which is characterized by stable morphological and technical features. These include vessels of complex shape with profiling at the top (the simplest form is less common) having sharpened or rounded bottom. On the outer surface one can see the next stamped shovel wrapped with a thin cord, ribbed or smooth mallet. The characteristic signs of ceramics of Posolskaya type should also include the type located beneath the belt cut holes and the original form of the corolla, which is modeled by two tapes. In a number of cases in the area outside of the corolla there is a wide ribbon, which after finalization looks like a sub-triangular in cross-section or semi-oval roller. Along with this feature is widespread the method of thickening corolla without forming a convex bead. The corolla acquired the finished look after laying on a thin slice of the flagellum with its subsequent smearing.

The decor of Posolskaya type of ceramics has a set of unique features. The composition of the ornament is localized in the upper third of the vessels and is represented by a combination of horizontal straight lines drawn by the motives of and / or pinholes, a variety of gear stamps, stacks with a rectangular, curved and sharpened working edge in a technology of retreat or interruption. Sometimes there is an inclusion in the total horizontal line of drawing of vertical motifs. At the bottom the composition ends with groups of vertical and inclined lines delivered pinholes or triangles facing the top down, from which short vertical beams extend (Berdnikov, 2013: 212-213).
In various embodiments, ceramics of Posolskaya type is widespread in the south of Eastern Siberia. The finds from the excavations of its known localities of the Middle Yenisei, Angara Region, Upper Lena, the Baikal region and Transbaikalia.

A.P. Okladnikov linked ceramics of Posolskaya type, derived from excavation and duties in the areas of the Middle Yenisei, with complexes and Kitoi and Glazkovo time (Okladnikov, 1957: 36-37). L.P. Khlobystin shared this view, but with one amendment. He believed that Posolskaya ceramics applies only to Kitoi stage (Khlobystin, 1978: 96).

Large-scale works that were deployed in the 1970s by Irkutsk archaeologists on multilayer localities in the south of Central Siberia (Kazachka I, and Gorely Les), allowed to specify the type of dating of Posolskaya ceramics. N. Saveliev on the basis of 14C-date on V layer of the archeological site Gorely Les $(4880 \pm 180$ years ago) dated it back to the Late Neolithic period (Saveliev, 1989: 23). The dating of the underlying layer $\mathrm{Va}-$ $5430 \pm 120$ years ago (Berdnikova et al., 1991: 29). With the radiocarbon data are generally consistent with the results of archeologicalmagnetic studies of ceramics from the overlying layer IV, that is it possible to determine its age in the area of 4800 years ago (Burakov, Nachasova, 2008). At the beginning of the 1990s. received the dating from the site Posolskaya $-5750 \pm 110$ years ago (Konstantinov et al., 1995: 23). In the Western Baikal data are available from the Posolskaya complex V of the upper layer of the site Sagan-Zaba II, which age is set in the range of 5600 (5500) -5000 (4900) years ago (Dolganov et al., 2013: 129-130).

Information obtained as a result of excavations in the basin of the Middle Yenisei makes it possible to determine the lower chronological boundary of Posolskaya ceramics. The oldest currently its findings recorded in the 
horizon of the cave Eleneva 11D with 14C-dates of $6900 \pm 115$ years ago, $6530 \pm 60$ years ago and in the layer VII Kazachka I, the age of which fits into the range 6800-6600 years ago in accordance with the dating of the above and the underlying horizons (Vorobieva, Saveliev, 1984: 149). As the upper limit of chronological rage acts 14C-date on the layer III of the site Nyasha $-4080 \pm 60$ years ago later on buried soil with Posolskaya pottery from the coastal outcrop of the terrace area location received another date $-5445 \pm 75$ years ago (Makarov, 2012: 69 ).

Ceramics similar to Posolskaya type, which is common in the Transbaikal region, in particular in the area of Vitim plateau, V.M. Vetrov attributed to Ust-Yumurchenskaya culture. During its existence in the area he identified in the range 5000 (4600) -3500 years ago on the basis of $14 \mathrm{C}$ dates obtained by excavation of materials in multilayer sites in the estuary. of the Karenga. (Vetrov, 2011: 34-35).
Determining the age of Ust-Yumurchenskaya culture requires clarification, especially its upper chronological border. But if you talk about the south of Central Siberia without absolute and relative timekeeping transbaikalian materials, time of existence and distribution of Posolskaya ceramic tradition in the region should be established within the framework of 6900-4100 years ago (Berdnikov, 2013: 221). The boundaries of this range require clarification: the bottom with a significant error $14 \mathrm{C}$-dating, top - because of the presence at the moment just one date.

\section{Materials and Analysis}

At the heart of this study is an analysis of the collection of Posolskaya pottery obtained from excavations at multilayer archeological site named after Generalov (Fig. 1). The archeological site was open in 2009 by a detachment of the Irkutsk State University (S. Kogay) as part of the archaeological survey along the route of

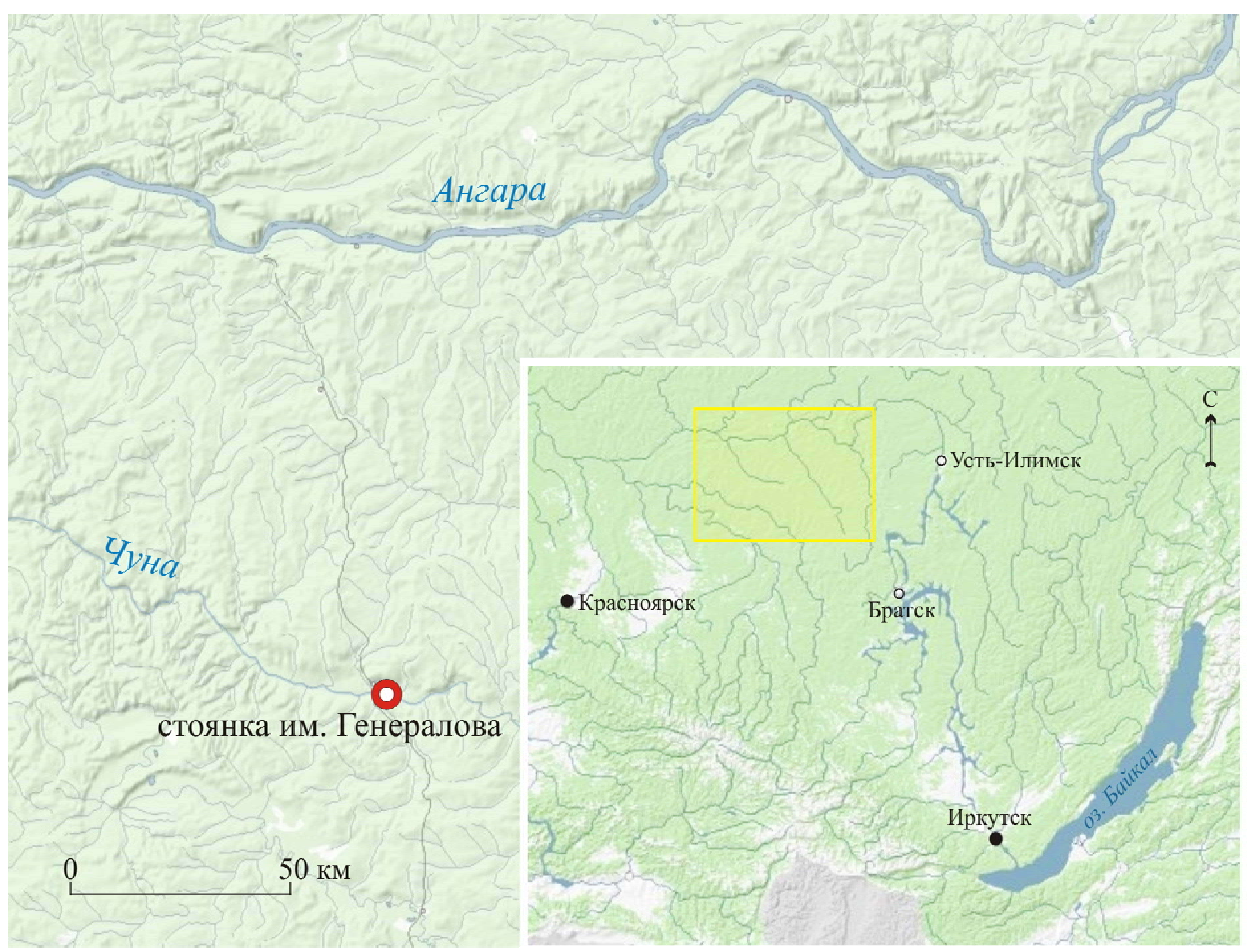

Fig. 1. Map showing the location of the archaeological site named after Generalov 
the pipeline Kuchetkan-Taishet. As a result of digging prospect holes on the right bank of the Chuna River (Taishet district of Irkutsk region) $2.8 \mathrm{~km}$ upstream from the mouth of the creek Sosnivka and $7.5 \mathrm{~km}$ from the village. The October (Boguchany district of Krasnoyarsk Region) recorded archaeological material, pre-dated Neolithic - Bronze Age. Part of the territory was an archeological site named after Generalov hit the main oil pipeline construction zone, after which it was decided to carry out rescue operations. In 2013, excavations were conducted at three sites, a total area of 10,966 m2 (Berdnikova et al., 2014). In 2014, carried out the final stage of the work, which resulted in further examined $3310 \mathrm{~m} 2$. Archaeological excavations in the study area revealed subaerial deposits genesis in a typical North Angara region in stratigraphic situation. Allocated 4 culturally significant horizons, which dated to a wide chronological range from the Neolithic to the Middle Ages (ibid: 179-184). Posolskaya ceramics recorded in the 2nd and 3rd horizon to. And was attributed by us to the late Neolithic stage. Excavations in 2014 revealed complex hearths with a concentration at the site of the Posolskaya type fragments of vessels, as well as guns and debitage of chalcedony. The presence of a fireplace faunal remains and coal suitable for radiocarbon dating, probably soon will allow to determine the age of the complexes.

A total of 539 fragments were analyzed belonging to at least 17 Posolskaya type vessels. In accordance with the nature of the design of the corolla are two options of containers: with a vividly expressed stucco molding as wide a triangular bead on the outside and with thickened rim without roller.

When forming the vessels wall stamping technique was used with the help of the mallet (shoulder blade) with a wrapped cord. Signs of knock-ribbed and smooth mallet are less common.
One copy of the considered collection marked uncharacteristic Posolskaya ceramic prints. The surface of this instance is stamped with a mesh mallet, prints which form the so-called technical waffle decor. The clearest traces are located in the bottom part. In favor of the use of knockout in all cases, in addition to the technical characteristic "pattern" on the outer surface, shows a number of features: a thin shard (up to $0.3-0.4 \mathrm{~cm}$ ) and fairly firm its structure, orientation fines rock (gravel) plane parallel walls and has slit-like shape.

Despite the long history of studying of Posolskaya ceramics, comprehensive technical and technological analysis of it was not performed, so that has not yet been installed construction vessels. The task is complicated by the fact that the vessels were beaten out very carefully, and in most cases, the space in a break junctions clearly recorded, and the pattern of cracking, at first glance, is sporadic.

The analysis of Posolskaya vessels from the archeological site named after Generalov at this stage of the study does not reveal the type and design stages of the program, but only some of its aspects. Note that in some vessels visible cracks in structural junctions. Their planigraphy indicates that the data items are made from ribbons (width latching about 4-5 cm). Signs of clay mass flow in the fracture due to the crock knockout read clearly, is particularly difficult to detect them in the field of the body, where the wall thickness reaches a minimum. Despite the fact that in several cases the use of a method for designing tapes of the bundle in the areas of junctions are virtually absent. The exceptions are two vessels, which are described below.

Some aspects of stamping also remain unclear. Complex configuration vessels with profiling in the estuary area and the peculiar form of the bottoms suggest the use of the simulation and dislodging a soft form of the base, which allows you to easily change the contour of the 
vessel. However, this working hypothesis requires verification.

Separately discuss the characteristics of the previously nobody celebrated a kind of techniques which traces recorded in the detailed analysis of the collection. Our attention was drawn to 14 fragments of the body and the finishes of the two vessels, which stratified by junctions of the ribbons (Fig. 2, 3).

In fractures formed by junctions of the ribbons are clearly visible parallel, located close to each other straight grooves. On the fragments belonging vessel number 1 (Fig. 2, 1, 3; Fig. 3, 2, 3), their width varies between $1-1.7 \mathrm{~mm}$ from the
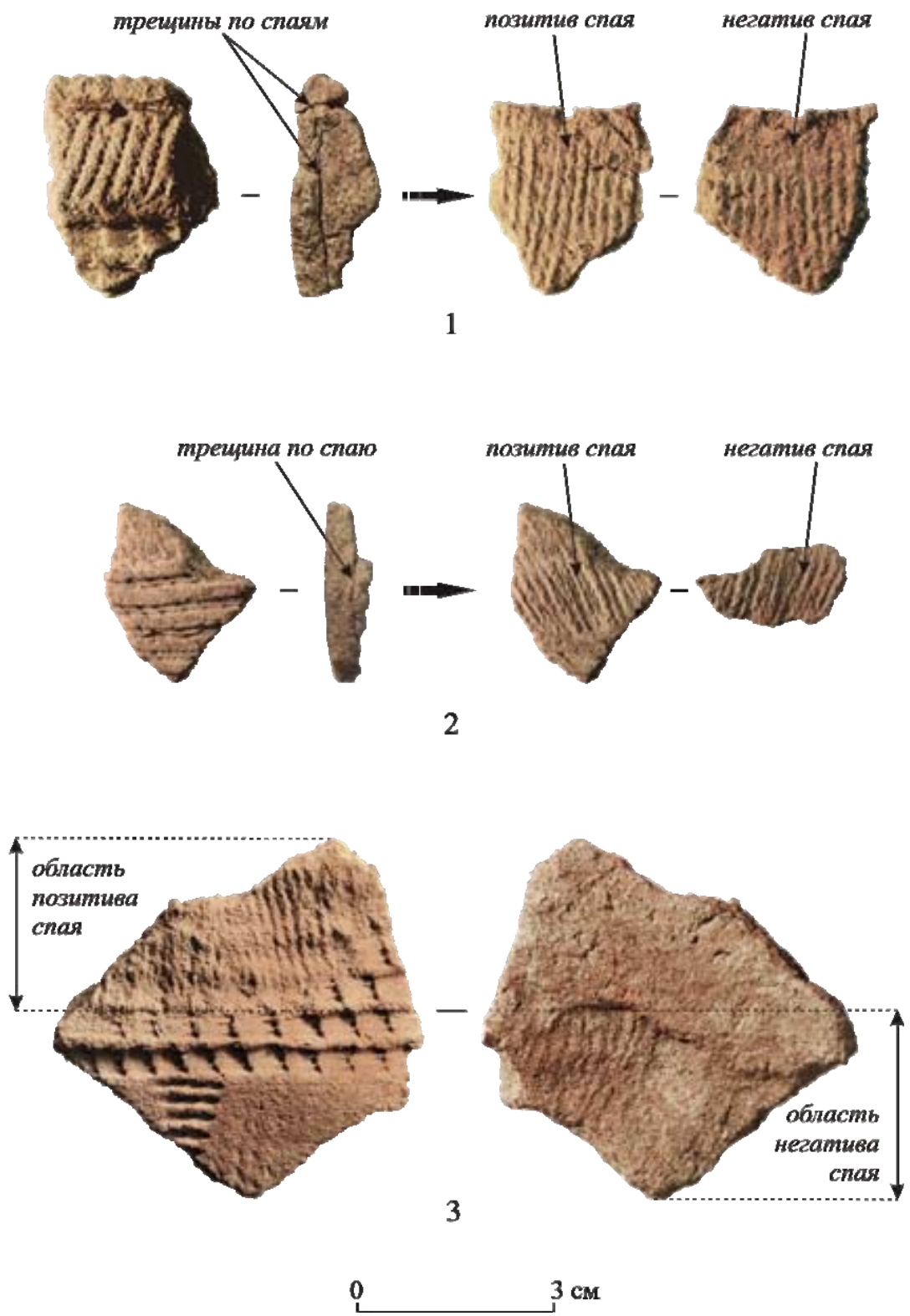

Fig. 2. Fragments of vessels of Posolskaya type from the archaeological site named after Generalov: 1 -a fragment of the corolla with the bundle on junction, 2 - a fragment of the body with the bundle on junction, 3 - a fragment of the body with peeling in the positive and negative junction 


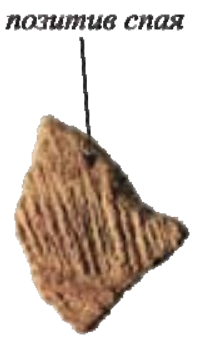

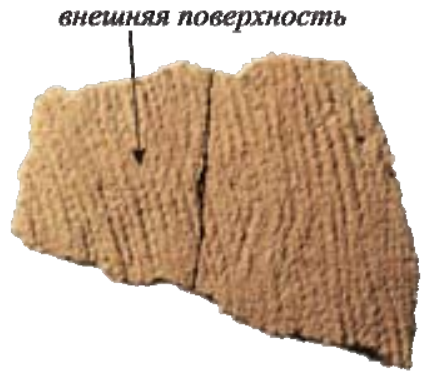

1

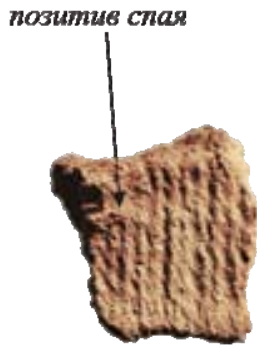

внешния поверхность

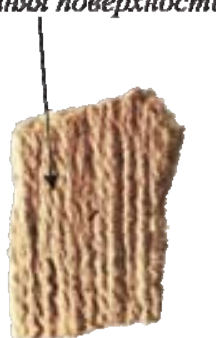

2

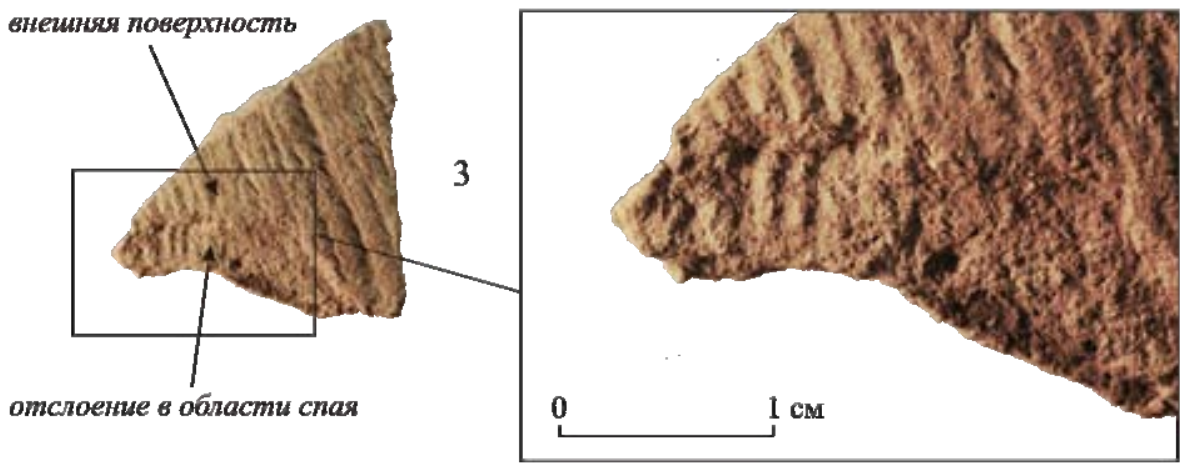

0 $3 \mathrm{~cm}$

Fig. 3. Fragments of vessels of Posolskaya type from the archaeological site named after Generalov: 1 - fragments of the body with prints in the peel and on the outer surface, 2 - parts of the body with prints in the peel and on the outer surface, $3-$ a fragment of the body with peeling in the junction

wreckage number vessel 2 (Fig. 2, 2; Fig . 3: 1) in the range of $0.5-1 \mathrm{~mm}$. Upon closer inspection, we can say that it prints twisted cords. Trails are predominantly in vertical direction relative to the axis of the vessel and visible only at the junction with the tapes bundle shard in a horizontal fracture, they are not fixed.

On the surface of both vessels read the following stamping mallet wrapped cord. Visually, there is a close resemblance to the tracks in crevices and on the outer surface (Fig. 3), it is particularly well fixed to the container number 2 , which used a thin cord.

\section{Discussion}

At this stage of the study can be argued that in the manufacture of vessels used Posolskaya stamping surface of a variety of mallets, among which is the predominant technique using a cord. We have described above case of sputtering using a cellular beater marked the first time. It is important to emphasize that the shake-out as a technique in general is not something special. It is fixed to the vast majority of Neolithic vessels south of Central Siberia and adjacent areas - early net-impressed, Khaita (corded), Ust-Belaya, 
Serovo, Late Serovo, Isakovo and Aplinskay pottery (Berdnikov, 2013).

More recently, it was believed that the technical decor of vessels largely determines the cultural identity of ceramic complexes. But recent studies suggest that it can in no way act as the main cultural marker when viewed outside of the complex features. We are aware of, in particular, copies of reprints with woven mesh relating to receptacles of Ust-Belaya type, which is characterized mainly by stamping smooth mallet (Kogay, Berdnikov, 2013). Ust-Belaya ceramics and prints of fixed cord (Tsydenova, 2012: 241). Serov and surface vessels of Late Serovo type also handle different tools (smooth and ribbed beater) or beaten out through the mesh net (Berdnikov, 2013: 211).

In this study, the described above technique using a cord is of particular interest. Its traces were recorded in the junctions tapes of Posolskaya vessels. Identification of the origin of textile prints on ceramics - one of the topical issues in the study of ancient pottery techniques. The most significant development in this area belong to I.G. Glushkov and T.N. Glushkova (Glushkov, Glushkova, 1992; Glushkov, 1996). Based on the experience of predecessors and the latest research, we have considered the main two main versions of the origin of cord prints:

1) Use of the textile strip woven from yarns thick as the gasket in the joint tapes;

2) Preparation of the tape, embossed its processing before connecting with the next tape.

The first version involves the use of plaited bands as a basis in the junction ribbons bearing the function of strengthening the joints in order to prevent cracking and deformation of the vessel in the process of creative and adapter stage. In the scientific literature of the ancient pottery repeatedly noted the use of organic additives with reinforcing functions (wool, feathers, droppings, chopped grass and straw), added directly to the molding composition at the stage of its preparation (Zhuschihovskaya 2004: 64-65). In our case, the variant with the reinforcement to be added at the stage of forming the vessel. Remote analogy can be made with the technique, which is marked by the analysis of Neolithic vessels from the excavation of the multi-layer location Tytkesken-2 in the Altai. In the process of forming vessels were wrapped around hair, which then «Plasterer» patches of clay. This prevents deformation of the coil of plastic material and vertical cracking during drying and sedimentation of the vessel under its own weight, i.e. it performed a reinforcing function (Kiriushin et al., 2012: 50).

The second version of the method involves the use of artificial deformation bands, which are usually caused by a long break in the molding. Additional processing of the dried strips at the junction, as we know, can increase the grip ends, and this technique has already been noted in the analysis of archaeological ceramics (Glushkov, 1996: 37-38). If you treat the reconstruction from this point of view, it can be assumed that the prints were formed as a result of the processing of positive and negative junction dried up tapes tool (stick, spatula) with a cord. The closest analogue is the technique noted in the course of experimental modeling of Odino-Krohalevo type of Bronze Age in Western Siberia (Glushkov, 1996: 102-103), where were junctions of recorded tapes, textile prints. I.G. Glushkov came to the conclusion that in this case, the shakeout is not used fabric and carving mallet, processing which created a simulation of textile prints. Each tape individually was stamped with a mallet. The presence of characteristic traces in the junctions due to overlaying each subsequent tape to the previous tape with a corrugated surface.

Apparently, a similar technique was used for manufacturing the vessels of Posolskaya type from the archaeological site named after 
Generalov. This assumption is evidenced by a number of features. As already noted, in a horizontal fracture fragments, which are stratified junctions of cord prints, no trace is not fixed. Corded base, burnt during firing, be sure to leave in a horizontal fracture traces in the form of small holes. In addition, the junction surfaces of tapes facing outwards, clear prints of the cords are fixed at their opposite tapes - negatives, prints data, with less distinct guttered edges (Fig. 2, 1, 2). When connecting the fragments convex relief elements in a belt junction coincides with the grooves on the other. Thus, the surface, where there are imprints cords is positive, and the opposite - negative junction. Negative prints of cord could be formed only if the tape was positive dried up, which in turn indicates a break in the molding. Drying tapes during simulation due, apparently, the design of the vessel. Most of them are rather large, with a mouth diameter of $30 \mathrm{~cm}$ and a height of about $30-40 \mathrm{~cm}$, with a wall thickness in the region of the body reaches $0.3 \mathrm{~cm}$. By itself, a process which involves a break in molding belts with dry sufficiently rational if the construction is carried out without the use of the base form. Otherwise, there is a high risk of deformation of large thinwalled vessel as a result of settling under its own weight.

This hypothesis of the origin of cord prints junctions tapes on Posolskaya type vessels seems to be the most acceptable and reasoned. The version proposed by us earlier, involving the use of braided strips of textile cords as reinforcement in the junctions (Ulanov, 2014), was not confirmed in the course of further research. Track, recording tapes junctions in stratified Posolskaya vessels at the archeological site named after Generalov, formed as a result a fairly rare admission that in Siberia before celebrated on research techniques forming vessels of krohalevskya type. Each subsequent tape should overlap the previous dried up the tape with a corrugated surface, which was stamped by a cord mallet, and in turn was treated in a similar way. As a result, the negative junction mirror imprinted with positive prints of the cord tape. Footprints in fiber junctions are recorded only if the positive was too dry.

Returning to the problem of diagnostics of the program of constructing vessels of Posolskaya type, we note that one of the pieces from the archeological site named after Generalov localization was seen as positive and negative (Fig. 2, 3). Due to the ornament on the fragment easily determined by its orientation. Given the nature of the location of areas of junction can be subjected to analysis of two variants of the type and direction of forming the vessel. The first option - the construction of the vessel from the mouth. In this case, the use of the base form can not be out of the question, so each subsequent tape must be connected to the previous inside. However, the positive junction with cord prints positioned in the outer portion of the belt situated closer to the mouth, which is impossible with this method of forming. The second embodiment involves forming the container bottom (use of base form is not excluded). It is doubtful that in this case applied or bottom of bottom-capacitive program for Posolskaya ceramics characterized by a rounded bottom and sharpened form. In this case, we can consider the hypothesis of using capacitive program upward direction followed by coupling with the bottom manufactured separately.

In any case, based on the analysis of a single fragment it is premature to make any conclusions. First of all, because of the program and the direction of the molding is determined on the basis of cumulative analysis of a number of features that include, along with the nature of the positive-negative junction especially the mouth part of the modeling, design and connection of 
the bottom. Recent signs have not been able to diagnose, because of the small number of pieces of the bottom part of the vessel.

\section{Conclusion}

Identification of characteristic and specific features of Neolithic pottery of the south of Central Siberia offer ways for solving problems relevant for the Siberian archeology problems in the study of the dynamics of historical and cultural processes.

As a result of this study we identified a number of aspects of the molding technique in Posolskaya vessels. The characteristic features of this type of design are the vessels of the tapes and a variety of stamped surface mallets. Noted in the analysis of archaeological collections from the archeological site named after Generalov and characterized by us with a peculiar technique on ceramics of the south of Central Siberia, which was detected for the first time. There are analogs to it in the materials of the Bronze Age in Western Siberia. In order to confirm our findings we need to continue the search for such traces on the corded ware in the south of Central Siberia, including Khaita type. Diagnostics of this technique, in our opinion, is the key to the reconstruction of the molding technology of vessels of Posolskaya type. In order to identify the type of program and the characteristics of their design we should additionally carry out a series of experimental studies, as a result we are likely to be able to confirm one of the versions or to obtain new information.

\section{References}

1. Berdnikov I.M. (2013). Key aspects of historical and cultural processes in south central Siberia in the Neolithic period (based on the ceramic complexes) [Klyuchevyye aspekty istoriko-kul'turnykh protsessov na yuge Sredney Sibiri v epokhu neolita (po materialam keramicheskikh kompleksov)]. Irkutsk State University, Series: Geoarcheology. Ethnology. Anthropology. (1 (2), Pp. 203-229.

2. Berdnikova N.E., Lezhnenko I.L., Saveliev N.A., Medvedev G.I., Georgievskaya G.M. Index of archaeological sites of the Irkutsk region: materials for the Body of historical and cultural monuments of the Irkutsk region [Ukazatel' arkheologicheskikh pamyatnikov Irkutskoy oblasti: materialy k Svodu pamyatnikov istorii i kul'tury Irkutskoy oblasti]. Usolsky area. Irkutsk, "Uprpoligrafizdat Press", 1991. 112 p.

3. Berdnikova N.E., Rogovskaya E.O., Berdnikov I.M., Lipnina E.A., Lokhov D.N., Dudarek S.P., Sokolova N.B., Timoshenko A.A., Popov A.A., Kharlamova N.V. (2014). Archeological site named after Generalov (River Chuna). Results of the rescue operation in 2013 [Stoyanka im. Generalova (r. Chuna). Rezul'taty spasatel'nykh rabot 2013 goda]. Irkutsk State University, Series: Geoarcheology. Ethnology. Anthropology. Vol. 7. Pp. 150-191.

4. Burakov K.S., Nachasova I.E. (2008). Archeomagnetic research of materials from the sites in Eastern Siberia, Gorely Les and Ust-Hite [Arkheomagnitnyye issledovaniya materialov pamyatnikov Vostochnoy Sibiri Gorelyy Les i Ust'-Khayta]. Physics of Earth. (3). Pp. 84-91.

5. Vetrov V.M. Archaeology of Vitim Plateau: Ust-Yumurchenskaya Culture (5-4,6-3.5 thousand years ago) [Arkheologiya Vitimskogo ploskogor'ya: ust'-yumurchenskaya kul'tura (5-4,6-3,5 tys. l. n.)]. Ancient cultures of Mongolia and the Baikal in Siberia. Irkutsk, 2011. (2). Pp. 34-41.

6. Vorobyova G.A., Saveliev N.A. Structure and age of cultural deposits of the multilayer settlement "Kazachka I". Problems of Research of the Stone Age of Eurasia (the 100th anniversary of the discovery of the Paleolithic in the Yenisey) [Stroyeniye $i$ vozrast kul'turovmeshchayushchikh 
otlozheniy mnogosloynogo poseleniya Kazachka I. Problemy issledovaniya kamennogo veka Yevrazii (k 100-letiyu otkrytiya paleolita na Yeniseye)]. Krasnoyarsk, 1984. Pp. 144-150.

7. Glushkov I.G. Pottery as an archaeological source [Keramika kak arkheologicheskiy istochnik]. Novosibirsk, Publishing House of the IAE SB RAS, 1996. 328 p.

8. Glushkov I.G., Glushkova T.N. Textile ceramics as a historical source (based on the Bronze Age in Western Siberia) [Tekstil'naya keramika kak istoricheskiy istochnik (po materialam bronzovogo veka Zapadnoy Sibiri)]. Tobolsk Tobolsk Publ. ped. Inst, 1992. 130 p.

9. Dolganov V.A., Goryunova O.I., Novikov A.G., Weber A.V. (2013). Complexes with ceramics of Posolskaya type in the Neolithic Baikal region: On materials of the V upper layer of the geoarchaeological, object Sagan-Zaba II [Kompleksy s keramikoy posol'skogo tipa $v$ neolite Pribaykal'ya: po materialam V verkhnego sloya geoarkheologicheskogo ob"yekta Sagan-Zaba II]. Bulletin of Novosib. state. Univ. Ser.: history, philology. (Vol.12, № 7). Pp. 127-132.

10. Zhuschihovskaya I. Studies in the History of ancient pottery Russian Far East [Ocherki istorii drevnego goncharstva Dal'nego Vostoka Rossii]. Vladivostok, Far East Branch of Russian Academy of Sciences, 2004. 312 p.

11. Kiriushin K. Yu, Kiriushin Y.F., Glushkov I.G. (2012). The use of animal hair in the pottery traditions of the Neolithic settlement complexes Tytkesken-2 [Ispol'zovaniye volosa zhivotnykh $v$ goncharnoy traditsii neoliticheskikh kompleksov poseleniya Tytkesken'-2]. Archaeology, Ethnology and Anthropology of Eurasia. (4 (52), Pp. 41-50.

12. Kogay S.A., Berdnikov I.M. (2013). Neolithic materials on Martynov village location (North Angara) [Neoliticheskiye materialy mestonakhozhdeniya Derevnya Martynova (Severnoye Priangar'ye)]. Irkut. state. Univ. Series: Geoarchaeology. Ethnology. Anthropology. 2(3). Pp. 124137.

13. Konstantinov N.V., Bazarova L.D., Semina L.V. Ancient settlement Posolskoye (new materials) [Drevneye poseleniye Posol'skoye (novyye materialy)]. Culture and monuments of the Bronze and Early Iron Ages of Buryatia and Mongolia. Ulan-Ude, 1995. Pp. 18-25.

14. Makarov N.P. Pottery of Posolskaya type in the Baikal and Central Siberia [Keramika posol'skogo tipa v Baykal'skoy i Sredney Sibiri]. Ancient cultures of Mongolia and the Baikal in Siberia. Ulaanbaatar, 2012. (3). Pp. 67-72.

15. Okladnikov A.P. (1957). From the history of ethnic and cultural ties between the Neolithic tribes of the Middle Yenisei (On the origin of Samodian tribes) [Iz istorii etnicheskikh i kul'turnykh svyazey neoliticheskikh plemen Srednego Yeniseya ( $k$ voprosu o proiskhozhdenii samodiyskikh plemen)]. Soviet archeology. (1). Pp. 7-38.

16. Savelyev N.A. The Neolithic Age of the South of Central Siberia (history of major ideas and modern state of the problem) [Neolit yuga Sredney Sibiri: (istoriya osnovnykh idey $i$ sovremennoye sostoyaniye problemy) ]: abstract to the dissertation of the Candidate of History. Novosibirsk, 1989. 25p.

17. Ulanov I.V. New aspects of molding technology of corded pottery of Posolskaya type. Modern problems of the ancient and traditional cultures of the peoples of Eurasia [Novyye aspekty formovochnoy tekhniki shnurovoy keramiki posol'skogo tipa. Sovremennyye problemy drevnikh $i$ traditsionnykh kul'tur narodov Yevrazii]. Krasnoyarsk, Siberian Federal University Press, 2014. Pp. 89-91.

$$
-583-
$$


18. Khlobystin L.P. (1978). Age and the ratio of the Neolithic cultures of Eastern Siberia [Vozrast $i$ sootnosheniye neoliticheskikh kul'tur Vostochnoy Sibiri]. Brief reports of the Institute of Archaeology. (153). Pp. 93-99.

19. Tsydenova N.V. (2012). Ceramics with cord imprints in the Baikal region and adjacent territories. Eurasia in the Cenozoic. Stratigraphy, paleoecology culture [Keramika so shnurovymi otpechatkami $v$ Baykal'skom regione $i$ na sopredel'nykh territoriyakh. Yevraziya $v$ kaynozoye. Stratigrafiya, paleoekologii kul'tury]. (1). Pp. 239-246

20. Tsydenova N.V., Khamzina E.A. (2006) Ceramic materials of Posolskaya archeological site: correlation and interpretation options [Keramicheskiye materialy posol'skoy stoyanki: korrelyatsii $i$ varianty interpretatsii]. Laboratory of ancient technologies. (4). Pp. 265-273.

\title{
Некоторые аспекты формовочной техники керамики посольского типа юга Средней Сибири
}

\author{
И.М. Бердников, И.В. Уланов \\ Иркутский государственный университет \\ Россия, 664003, Иркутск, ул. К. Маркса, 1
}

\begin{abstract}
Керамика посольского типа выделена в 1970-е г2. и получила наименование по эпонимной многослойной стоянке Посольская (Южное Прибайкалье). В различных вариантах посольская керамика широко распространена на юге Восточной Сибири. Интенсивные исследования многослойных стратифицированных объектов юга Средней Сибири позволили уточнить ее датировку. На данном этапе исследований время ее бытования в регионе можно датировать широким интервалом - 6900-4100 л. н. (некалиброванный возраст), границь которого требуют уточнения. В результате анализа посольских сосудов со стоянки им. Генералова (р. Чуна) вылялены некоторые аспекты формовочной техники. Установлено, что они конструировались из широких лент и тщательно выбивались. На двух сосудах зафиксировань следы использования своеобразного технического приема, который до этого отмечался по материалам бронзового века Западной Сибири. Каждая последующая лента накладывалась внахлест на предыдушую подсохшую ленту, внешняя поверхность которой была выбита шнуровой колотушкой, и обрабатывалась таким же образом. В результате на негативе спая зеркально отпечатывались оттиски шнуров с подсохшей позитивной ленты. Предложено два варианта формовки посольских сосудов: с устьевой части без использования формы-основы и снизу вверх с раздельным конструированием тулова и дна. Диагностика охарактеризованного выше технического приема является ключом к реконструкиии проиесса формования сосудов посольского типа. Для идентификации вида программы и особенностей конструирования следует дополнительно провести серию экспериментальных исследований.
\end{abstract}

Ключевые слова: Восточная Сибирь, неолит, технология древнего гончарства, керамика посольского типа, техника формовки.

Работа выполнена в рамках НИР Х.104.1.1 Института археологии и этнографии СО РАН.

Научная специальность: 07.00.00 - исторические науки. 